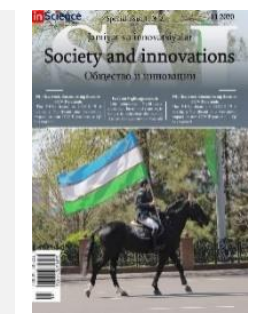

\title{
Rehabilitation features of patients with stroke in the vertebro- basillary system depending on the pathogenetic subtype of stroke
}

\section{Munisa BAKHADIROVA ${ }^{1}$}

Tashkent Institute for Advanced Training of Doctors

\begin{tabular}{l} 
ARTICLE INFO \\
\hline Article history: \\
Received September \\
2020Received in revised \\
form 15 November \\
2020Accepted 20 November \\
2020Available online \\
15 December 2020 \\
\hline
\end{tabular}

\section{Keywords:}

Stroke

Rehabilitation

Clinic changes

MRI

COPD

\section{ABSTRACT}

Ischemic stroke is a serious medical and social issue due to deep and prolonged disability, as well as social maladjustment of patients. In this regard, the aim of the research was to study the influence of pathogenetic subtypes of ischemic stroke on the rehabilitation possibilities.

Based on the presence of COPD (Chronic Obstructive Pulmonary Disease) we divided all patients into 2 groups

Patients with IS in VI (Vertebrobasilar Insufficiency) and COPD - 62 people (group I) - 29 men and 33 women aged 50 to 74 (59.8 \pm 5.8 ). Patients with IS in VI - 64 people (group II). Of these, 31 are men and 33 are women aged 51 to $80(62.4 \pm 5.4)$. All patients received traditional treatment in the most acute and severe periods of IS, patients with COPD received and treatment for COPD simultaneously with traditional IS therapy. The Barthel index was used to assess the patient's self-care capabilities. The degree of disability after IS was studied using the Rankin scale. In patients of subgroup II b, by the end of the ED (Eating Disorders), the indicators of the Lindmark B scale for the patient's general mobility differed significantly from the baseline at the beginning of the ED $(p=0.44)$. At that time, in the II a subgroup, only the indicators of the B. Lindmark scale were reliable.

In patients of subgroup II b, the difference in indicators at the beginning and at the end of ED was significant according to the Barthel index. Recovery in ED depends on many factors, including the subtype of IS, so the IS CE is the most severe, which is reflected in the Rankin scale. The timing and extent of patient recovery depends on the localization of the process, the subtype of IS, the presence of COPD, and the method of rehabilitation.

\footnotetext{
${ }^{1}$ Candidate of Medical Sciences, Associate Professor, Tashkent Institute for Advanced Training of Doctors, Tashkent, Uzbekistan

Email: m.bakhadirova@mail.ru
} 
Patients with the lacunar subtype, a single small or medium focus in the cerebellar hemispheres and midbrain recover most fully after complex rehabilitation.

2181-1415/C) 2020 in Science LLC.

This is an open access article under the Attribution 4.0 International (CC BY 4.0) license (https://creativecommons.org/licenses/by/4.0/deed.ru)

\section{Особенности реабилитации пациентов с инсультом в вертебро-базиллярной системе в зависимости от патогенетического подтипа инсульта}

\author{
Ключевые слова: \\ Инсульт \\ Реабилитация \\ Клинические проявления \\ МРТ \\ ХОБЛ;
}

\section{АННОТАЦИЯ}

Ишемический инсульт - серьезная медицинская и социальная проблема из-за глубокой и продолжительной инвалидности, a также социальной дезадаптации пациентов. В связи с этим целью исследования было изучение влияния патогенетических подтипов ишемического инсульта на возможности реабилитации.

На основании наличия ХОБЛ (хронической обструктивной болезни легких) мы разделили всех пациентов на 2 группы.

Пациенты с ИИ в VI (вертебробазилярная недостаточность) и ХОБЛ - 62 человека (I группа) - 29 мужчин и 33 женщины в возрасте от 50 до 74 лет $(59,8 \pm 5,8)$. Пациенты с ИИ в VI - 64 человека (II группа). Из них 31 мужчина и 33 женщины в возрасте от 51 до 80 лет $(62,4 \pm$ $5,4)$. Все пациенты получали традиционное лечение в наиболее острых и тяжелых периодах ИИ, пациенты с ХОБЛ получали лечение ХОБЛ одновременно с традиционной терапией ИИ. Индекс Бартеля использовался для оценки способности пациента к самообслуживанию. Степень инвалидности после ИИ изучалась по шкале Рэнкина. У пациентов подгруппы II б к концу ЭД (расстройства пищевого поведения) показатели шкалы Линдмарка В для общей подвижности пациента достоверно отличались от исходного уровня в начале ЭД $(\mathrm{p}=0,44)$. На тот момент во II подгруппе достоверными были только показатели шкалы Б. Линдмарка.

У пациентов подгруппы II б разница показателей в начале и в конце ЭД была достоверной по индексу Бартеля. Выздоровление при ЭД зависит от многих факторов, в том числе от подтипа ИС, поэтому ИС СЕ является наиболее тяжелым, что отражается в шкале Рэнкина. Сроки и степень выздоровления пациента зависят от локализации процесса, подтипа ИИ, наличия ХОБЛ и метода реабилитации. Наиболее полно после комплексной реабилитации выздоравливают пациенты с лакунарным подтипом, единичным малым или средним очагом в полушариях мозжечка и среднем мозге. 
Ischemic stroke is a serious medical and social issue in connection with profound and prolonged disability, as well as with social maladjustment of patients, which are caused in most cases by movement disorders, and residual effects of the transferred cerebrovascular accident of varying severity are detected in about $75 \%$ of patients.

The severity of the condition in the acute period and the volume of rehabilitation in the recovery period are often determined by the subtype of stroke. In this regard, the aim of the research was to study the influence of pathogenetic subtypes of ischemic stroke on the possibilities of rehabilitation.

Since in our study, among the studied patients, 62 patients had COPD in a co morbid background, we divided all patients into 2 groups according to the presence of COPD. Patients with IS in VI (Vertebrobasilar Insufficiency) and COPD - 62 people (group I) - 29 men and 33 women aged 50 to 74 (59.8 \pm 5.8 ). Patients with IS in VI - 64 people (group II). Of these, 31 are men and 33 are women aged 51 to 80 (62.4 \pm 5.4$)$.

All patients received traditional treatment in the most acute and severe periods of IS, patients with COPD received COPD treatment simultaneously with traditional IS therapy. The pathogenetic subtypes of ischemic strokes were determined according to the Trial of Org 10172 in Acute Stroke Treatment (TOAST) classification, which is currently the most widespread. We excluded IS with unspecified etiology from the study. To assess the patient's self-care capabilities, the Barthel's index (score for daily activities and the ability to care for oneself) was used (MH (Medical History)).

In the Barthel scale, the scores from 0 to 45 correspond to severe disability (significant or complete impairment of neurological functions), 50 to 70 points - moderate disability (limitation of neurological functions), 75 - 100 points - minimal limitation or preservation of neurological functions [5; 7]. The degree of disability after IS was studied using the Rankin scale [1].

To assess the neurological status in the early and late rehabilitation periods, we used the B. Lindmark scale, (score assessment of movement disorders (active and passive) [6], muscle tone, sensitivity, walking, balance, social skills). To assess the neuropsychological status of patients, we used in the early and late rehabilitation periods, the following scales:

The Montreal Cognitive Assessment Scale (MoCA) and the Hospital Anxiety and Depression Scale (HADS). In patients with different pathogenetic subtypes of IS in VI, the following significant differences in age were revealed.

Patients with EC subtype of IS were significantly older (average age $69.7 \pm 9.2$ years), patients with PA subtype (average age $58.8 \pm 8.7$ years) $(\mathrm{p}=0.016)$ and patients with HD subtype (average age 60, $3 \pm 9.4$ years) $(\mathrm{p}=0.026)$. Patients with RA subtype (average age $66.7 \pm 10.6$ years) did not have significant differences with any of the groups $(p>0.05)$.

In patients with different pathogenetic subtypes of IS in VI, the following significant differences were found in the assessment on the Rankin scale at discharge.

Patients with CE subtype of IS had higher scores on the Rankin scale at the end of treatment (average score $3.62 \pm 1.16$ points) compared to patients with AT subtype (average score $2.76 \pm 1.1$ points $)(p=0.011)$ and LA subtype (average score $2.79 \pm 0.76$ points) $(\mathrm{p}=0.041)$. Patients with HD subtype (average score $2.89 \pm 0.78$ ) did not differ significantly from any of the groups $(\mathrm{p}>0.05)$. 
Patients of group I with CE subtype scored significantly higher scores on the Rankin scale during the entire ED compared with patients with AT subtype $(p=0.011)$, LA subtype $(p=0.041)$ and HD subtype $(p=0.028)$, which is consistent with the data literature [3]. There was no significant relationship between different subtypes of IS with any other indicators, except for the Rankin scale $(-0.14<\mathrm{r}<0.14)$.

In patients of group I, we found a moderately strong direct significant $(p<0.05)$ relationship between the number of points on the Rankin scale and the number of points on the HADS Anxiety scale $(r=0.46)$, HADS Depression $(r=0.50)$ and the on scale B. Lindmark ( $r=0.48)$ for CE subtype of IS; average strength, a direct significant $(p<0.05)$ relationship between the number of points on the Rankin scale and the number of points on the HADS Anxiety scale ( $r=0.47)$, HADS Depression $(r=0.51)$ with AT subtype of IS. With LA and HD subtypes of IS in patients of group I , it was not possible to determine the relationship among indicators of various scales due to the small number of patients)

The sum of points on the B. Lindmark scale for the study within 3 months from the onset of ED and at the end of ED had a significant difference $(p=0.43)$ in subgroup II $b$ and was not significant $(\mathrm{p}=0.55)$ in subgroup II a (table 4.6).

In patients of subgroup II b, by the end of ED, the indicators of the scale Lindmark $B$. in terms of the patient's general mobility differed from the baseline at the beginning of ED significantly $(p=0.44)$, with a significant difference in all other indicators, including the total score $(\mathrm{p}<0.05)$. At that time, in subgroup II a, only the indicators of the B. Lindmark scale are reliable, such parameters as the doing active hand movements $(p=0.48)$, joints' mobility $(p=0.47)$ and the strength of pain in them $(p=0.48)$

All other indicators of the B. Lindmark scale did not have significant differences at the beginning and end of ED ( $p>0.05)$. In patients of subgroup II $b$, the difference in indicators at the beginning and end of ED was significant according to Barthel's index $(\mathrm{p}=$ $0.44)$, HADS Anxiety scale ( $p=0.43)$ and HADS Depression $(p=0.45)$. In II a subgroup, the difference in indicators at the beginning and at the end of ED was significant only according to the Barthel index $(p=0.46)$ (Table 4.6).

The difference in indicators at the beginning and at the end of ED were not significant according to the MoCA scale and in both subgroups of group II ( $p>0.05)$, which coincides with the results of group I, which is associated with less impairment of cognitive functions in IS in VI.

Patients of group II with CE subtype, as well as patients of group I with CE of IS, gained significantly higher scores on the Rankin scale during the entire ED compared with the patients of AT subtype $(\mathrm{p}=0.037)$, LA subtype $(\mathrm{p}=0.042)$ and HD. subtype $(\mathrm{p}=$ 0.039)

In patients of group II, we found a moderately strong direct reliable $(p<0.05)$ relationship between the number of points on the Rankin scale and the number of points on the HADS Anxiety $(r=0.44)$, HADS Depression $(r=0.46)$ and B. Lindmark $(r=0.47)$ with CE subtype of IS;

the average strength, a direct reliable $(\mathrm{p}<0.05)$ relationship between the number of points on the Rankin scale and the number of points on the scale HADS Anxiety $(\mathrm{r}=$ 0.44), HADS Depression ( $r=0.48$ ) with AT subtype of IS. With LA and HD subtypes of IS in patients of group II, it was not possible to determine the relationship between the indicators of various scales due to the small number of patients. 
Conclusions: 1. Recovery in ED depends on many factors, including the subtype of IS , so the most severe is the CE of IS , which is reflected in the Rankin scale, the AT subtype is also quite difficult, LA and HD subtypes are reliably easier.

2. Each localization of IS in VI is characterized by its own changes in the patient's neurological status, Doppler indices and MRI picture.

3 . The timing and the volume of recovery depends on the localization of the process, the subtype of IS, the presence of COPD and the method of rehabilitation.

4. Patients with a lacunar subtype, a single small or medium focus in the cerebellar hemispheres and the midbrain are qualitatively fully restored after complex rehabilitation.

Ischemic stroke is a serious medical and social issue in connection with profound and long-term disability, as well as with social maladjustment of patients, which are caused in most of cases by movement disorders, and residual effects of the cerebrovascular accident of varying severity is detected in about $75 \%$ of patients. And even after intensive rehabilitation measures, moderate or severe disability remains in $25-50 \%$ of patients. The severity of the condition in the acute period and the volume of rehabilitation in the recovery period are often determined by the subtype of stroke. In this regard, the aim of the research was to study the influence of pathogenetic subtypes of ischemic stroke on the possibilities of rehabilitation.

Since in our study, among the studied patients, 62 patients had COPD in a co morbid background, we divided all patients into 2 groups according to the presence of COPD. Patients with IS in VI and COPD - 62 people (group I) - 29 men and 33 women aged 50 to 74 (59.8 \pm 5.8). Patients with IS in VI - 64 people (group II). Of these, 31 are men and 33 are women aged 51 to $80(62.4 \pm 5.4)$. All patients received traditional treatment in the most acute and severe periods of IS, patients with COPD received COPD treatment simultaneously with traditional IS therapy. The pathogenetic subtypes of ischemic strokes were determined according to the Trial of Org 10172 in Acute Stroke Treatment (TOAST) classification, which is currently the most widespread. We excluded IS with unknown etiology from the study [2; $4 ; 8]$.

To assess the patient's self-care capabilities, the Barthel index (score for daily activities and the ability to care for oneself) ( $\mathrm{MH}$ ) was used. On the Barthel scale, the scores from 0 to 45 correspond to severe disability (significant or complete impairment of neurological functions), 50 to 70 points - moderate disability (limitation of neurological functions), 75 to 100 points - minimal limitation or preservation of neurological functions $[5 ; 7]$.

The degree of disability after IS was studied using the Rankin scale [1].

To assess the neurological status in the early and late rehabilitation periods, the B. Lindmark scale was used, (a point assessment of movement disorders (active and passive) [6], muscle tone, sensitivity, walking, balance, social skills). The Lindmark scale includes 7 subscales that characterize various parameters of the motor system, sensitivity and coordination: subscale A - performing active movements in the arm and leg, B - performing rapid variable movements, $\mathrm{C}$ - general mobility of the patient, $\mathrm{D}$ - balance parameters, $\mathrm{E}$ state superficial and deep sensitivity, F - the strength of pain in the joints and G - mobility in them.

Each parameter is evaluated in points and has a different maximum for each parameter. The point estimate is maximum in case of normal function (a healthy one can score a maximum of 446 points) and is equal to zero in the case of the greatest severity of 
disorders. The degree of decrease in the integral indicator correlates with the severity of the functional consequences of AISA (Acute Ischemic Cerebrovascular Accident) [6].

To assess the neuropsychological status of patients, we used the following scales in the early and late rehabilitation periods: the Montreal Cognitive Assessment Scale (MoCA) and the Hospital Anxiety and Depression Scale (HADS).

Research results:

Clinical and epidemiological characteristics of patients with different pathogenetic subtypes of IS in VI (Vertebrobasilar Insufficiency) $(\mathrm{M} \pm \sigma)$

\begin{tabular}{|c|c|c|c|c|c|}
\hline \multicolumn{2}{|c|}{ 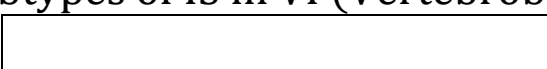 } & AT $(n=55)$ & CE $(n=39)$ & LA $(n=14)$ & $\mathrm{HD}(\mathrm{n}=18)$ \\
\hline \multicolumn{2}{|c|}{ Average age, years } & $66,7 \pm 10,6$ & $69,7 \pm 9,2^{*}$ & $58,8 \pm 8,7$ & $60,3 \pm 9,4$ \\
\hline \multicolumn{2}{|c|}{$\begin{array}{l}\text { Average BMI (Body Mass } \\
\text { Index, , } \mathrm{kg} / \mathrm{m}^{2}\end{array}$} & $28,09 \pm 4,28$ & $26,3 \pm 6,4$ & $29,4 \pm 5,7$ & $31,2 \pm 4,4$ \\
\hline \multirow{2}{*}{$\begin{array}{c}\text { Rankin } \\
\text { scale score, } \\
\text { points }\end{array}$} & On admission & $3,75 \pm 0,91$ & $4,05 \pm 0,86$ & $3,77 \pm 0,53$ & $3,86 \pm 1,1$ \\
\hline & On discharge & $2,76 \pm 1,1$ & $3,62 \pm 1,16^{* *}$ & $2,79 \pm 0,76$ & $2,89 \pm 0,78$ \\
\hline \multirow{2}{*}{$\begin{array}{l}\text { NIHSS scale } \\
\text { score, } \\
\text { points }\end{array}$} & On adm & $5,93 \pm 3,35$ & $8,24 \pm 4,97$ & $5,43 \pm 1,40$ & $4,33 \pm 1,66$ \\
\hline & On discharge & $2,52 \pm 2,15$ & $2,53 \pm 2,89$ & $2,31 \pm 1,11$ & $2,19 \pm 1,45$ \\
\hline
\end{tabular}

Note: * patients with CE subtype are significantly older than patients with LA subtype $(p=0.016)$ and patients with HD subtype $(p=0.026)$; ${ }^{* *}$ Patients with CE subtype at the end of treatment had significantly higher scores on the Rankin scale compared to patients with AT subtype $(p=0.011)$ and LA subtype $(p=0.041)$.

In patients with different pathogenetic subtypes of IS in VI, the following significant differences in age were revealed. Patients with CE subtype IS were significantly older (average age $69.7 \pm 9.2$ years), patients with LA subtype (average age $58.8 \pm 8.7$ years) ( $p$ $=0.016)$ and patients with HD subtype (average age 60, $3 \pm 9.4$ years) $(p=0.026)$. Patients with AT subtype (average age $66.7 \pm 10.6$ years) did not have significant differences with any of the groups ( $p>0.05)$.

In patients with different pathogenetic subtypes of IS in VI, the following significant differences were found in the assessment according to the Rankin scale at discharge. Patients with CE subtype IS had higher scores on the Rankin scale at the end of treatment (average score $3.62 \pm 1.16$ points) compared to patients with AT subtype (average score $2.76 \pm 1.1$ points $)(\mathrm{p}=0.011)$ and LA subtype (average score $2.79 \pm 0.76$ points) $(\mathrm{p}=$ 0.041 ). Patients with HD subtype (average score $2.89 \pm 0.78$ ) did not differ significantly from any of the groups $(\mathrm{p}>0.05)$. 
The distribution of patients in group I on the pathogenetic subtype of IS is shown in Figure 1.

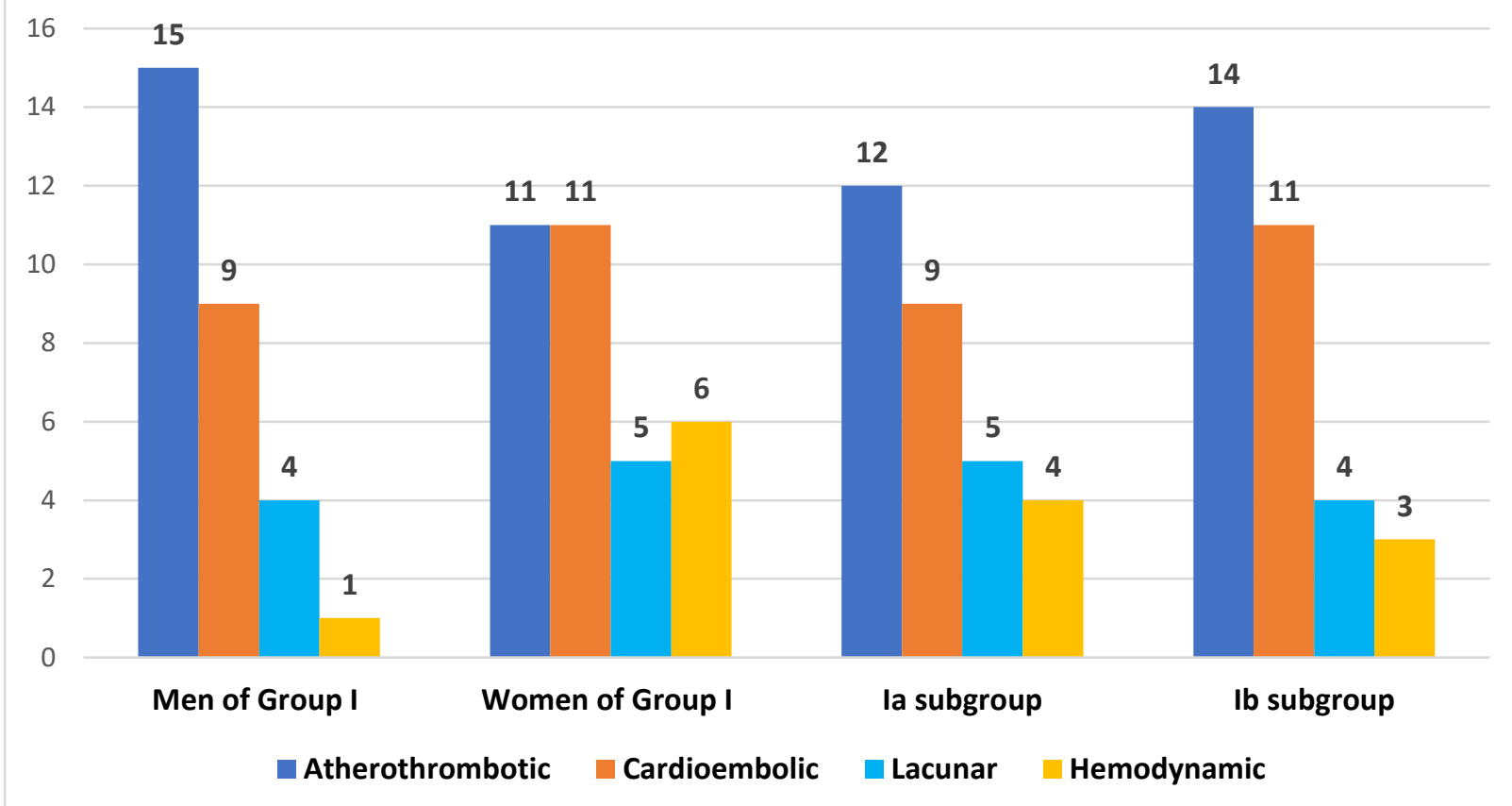

Figure 1 Distribution of patients in group I $(n=62)$ by pathogenetic subtypes by sex and subgroups

Figure 1 shows that the distribution of patients into subgroups according to the pathogenetic subtype of IS was steady, and by gender it was less steady in HD of IS.

The dynamics of indicators of clinical, neurological and neuropsychological scales for pathogenetic subtypes of IS in VI are presented in Table 1.

Patients of group I with CE subtype scored significantly higher scores on the Rankin scale during the entire ED compared with patients with AT subtype $(p=0.011)$, Lacunar subtype $(p=0.041)$ and HD subtype $(p=0.028)$, which is consistent with the data literature [3]. There was no significant relationship between different subtypes of IS with any other indicators, except for the Rankin scale $(-0.14<\mathrm{r}<0.14)$.

In patients of group I, we found a moderately strong direct significant $(\mathrm{p}<0.05)$ relationship between the number of points on the Rankin scale and the number of points on the HADS Anxiety $(r=0.46)$, HADS Depression $(r=0.50)$ and B. Lindmark $(r=0.48)$ with CE subtype IS; average strength, a direct reliable $(p<0.05)$ relationship between the number of points on the Rankin scale and the number of points on the HADS Anxiety scale $(r=0.47)$, HADS Depression $(r=0.51)$ with AT subtype IS. With LA and HD subtypes of IS in patients of group I, it was not possible to determine the relationship of indicators of various scales among themselves due to the small number of patients. 
Table 1

Dynamics of indicators of clinical, neurological and neuropsychological scales of patients of group I $(n=62)$ with different pathogenetic subtypes of IS in VI $(M \pm \sigma)$

\begin{tabular}{|c|c|c|c|c|c|}
\hline \multicolumn{2}{|c|}{ The studied indicators } & $\operatorname{AT}(n=26)$ & CE $(n=20)$ & LA $(n=9)$ & $\mathrm{HD}(\mathrm{n}=7)$ \\
\hline \multirow{3}{*}{$\begin{array}{l}\text { B. } \\
\text { Lindmark } \\
\text { Scale }\end{array}$} & ED onset & $324,9 \pm 13,4$ & $307,7 \pm 15,7$ & $326,3 \pm 22,4$ & $327,9 \pm 22,7$ \\
\hline & in 3 months & $331,7 \pm 12,7$ & $315,6 \pm 14,2$ & $341,4 \pm 19,1$ & $333,1 \pm 18,2$ \\
\hline & in 6 months & $343,3 \pm 12,1^{*}$ & $327,3 \pm 15,4$ & $349,2 \pm 15,3^{*}$ & $344,3 \pm 17,8$ \\
\hline \multirow{3}{*}{$\begin{array}{l}\text { Index } \\
\text { Barthel }\end{array}$} & ED onset & $39,1 \pm 3,4$ & $31,3 \pm 4,3$ & $43,1 \pm 5,2$ & $43,5 \pm 6,4$ \\
\hline & in 3 months & $43,2 \pm 3,7$ & $36,3 \pm 4,8$ & $47,1 \pm 7,8$ & $48,3 \pm 8,1$ \\
\hline & in 6 months & $50,5 \pm 4,6^{*}$ & $42,3 \pm 4,4^{*}$ & $53,6 \pm 6,2^{*}$ & $54,2 \pm 7,9$ \\
\hline \multirow[t]{3}{*}{$\begin{array}{l}\text { Rankin } \\
\text { Scale }\end{array}$} & ED onset & $3,79 \pm 1,31$ & $\begin{array}{l}4,15 \\
\pm 1,12^{* *}\end{array}$ & $3,58 \pm 1,26$ & $3,69 \pm 1,28$ \\
\hline & in 3 months & $3,42 \pm 1,84$ & $3,77 \pm 1,19^{* *}$ & $3,34 \pm 1,42$ & $3,36 \pm 1,46$ \\
\hline & in 6 months & $3,07 \pm 0,76$ & $3,43 \pm 1,21^{* *}$ & $3,02 \pm 1,41$ & $3,04 \pm 1,51$ \\
\hline \multirow[t]{3}{*}{ MoCA Scale } & ED onset & $21,4 \pm 2,1$ & $20,4 \pm 2,3$ & $22,7 \pm 2,8$ & $22,4 \pm 2,7$ \\
\hline & in 3 months & $23,6 \pm 2,4$ & $22,3 \pm 2,7$ & $24,7 \pm 3,3$ & $24,4 \pm 3,6$ \\
\hline & in 6 months & $24,6 \pm 2,8$ & $23,4 \pm 2,8$ & $25,8 \pm 3,4$ & $26,3 \pm 3,7$ \\
\hline \multirow{3}{*}{$\begin{array}{l}\text { HADS } \\
\text { Anxiety }\end{array}$} & ED onset & $11,96 \pm 1,73$ & $12,52 \pm 1,93$ & $11,07 \pm 2,71$ & $11,16 \pm 2,43$ \\
\hline & in 3 months & $10,87 \pm 1,54$ & $11,47 \pm 2,71$ & $10,36 \pm 2,78$ & $10,47 \pm 2,67$ \\
\hline & in 6 months & $9,78 \pm 1,26$ & $10,32 \pm 2,45$ & $9,17 \pm 2,68$ & $9,18 \pm 2,86$ \\
\hline \multirow{3}{*}{$\begin{array}{l}\text { HADS } \\
\text { Depression }\end{array}$} & ED onset & $11,34 \pm 1,68$ & $12,02 \pm 1,81$ & $10,74 \pm 2,36$ & $11,08 \pm 2,43$ \\
\hline & in 3 months & $10,13 \pm 1,74$ & $10,21 \pm 1,87$ & $10,08 \pm 2,17$ & $10,12 \pm 2,34$ \\
\hline & in 6 months & $9,71 \pm 1,45$ & $10,17 \pm 1,74$ & $9,27 \pm 1,94$ & $9,34 \pm 1,88$ \\
\hline NIHSS & ED onset & $2,51 \pm 1,85$ & $2,58 \pm 1,89$ & $2,31 \pm 1,51$ & $2,11 \pm 1,65$ \\
\hline
\end{tabular}

Note: * $-\mathrm{P}<0.05$ is significant in relation to similar indicators of this group at the beginning of ED; ${ }^{* *}-\mathrm{P}<0.05$ significant in relation to other IS subtypes in the same period

The average increase in the scores of the B. Lindmark scale in both subgroups of group II had a significant difference $(p<0.05)$ at the end of ED compared to the study within 3 months from the onset of ED, that is, the progress of recovery of the neurological status was obvious, but the total number points and the increase in points was significantly greater in subgroup II $b(p<0.05)$. The sum of points on the B. Lindmark scale to the study within 3 months from the onset of ED and at the end of ED had a significant difference ( $p$ $=0.43)$ in subgroup II $\mathrm{b}$ and was not significant $(\mathrm{p}=0.55)$ in subgroup II a (table 4.6).

In patients of subgroup II $b$, by the end of $E D$, the indicators of the B. Lindmark scale in terms of the patient's general mobility differed significantly from the baseline at the onset of ED $(p=0.44)$, with a significant difference in all other indicators, including the total score $(p<0.05)$. At that time, in subgroup II a, only the indicators of the B Lindmark 
scale are reliable, such parameters as the performance of active hand movements $(\mathrm{p}=$ $0.48)$, joint mobility $(p=0.47)$ and the strength of pain in them $(p=0.48) \ldots$ All other indicators of the B. Lindmark scale did not have a significant difference at the onset and end of ED ( $\mathrm{p}>0.05)$.

In patients of subgroup II $b$, the difference in indicators at the onset and end of the ED were significant according to the Barthel index $(\mathrm{p}=0.44)$, the HADS Anxiety scale $(\mathrm{p}$ $=0.43)$ and HADS Depression $(p=0.45)$. In subgroup II a, the difference in indicators at the onset and end of ED was significant only according to the Barthel index $(p=0.46)$ (Table 4.6).

The difference in indicators at the onset and end of ED were not significant according to the MoCA scale and in both subgroups of group II ( $p>0.05)$, which coincides with the results of group I, which is associated with less impairment of cognitive functions in IS in VI (Table 4.6). Distribution of patients in group II by pathogenetic subtype of IS is shown in Figure 2

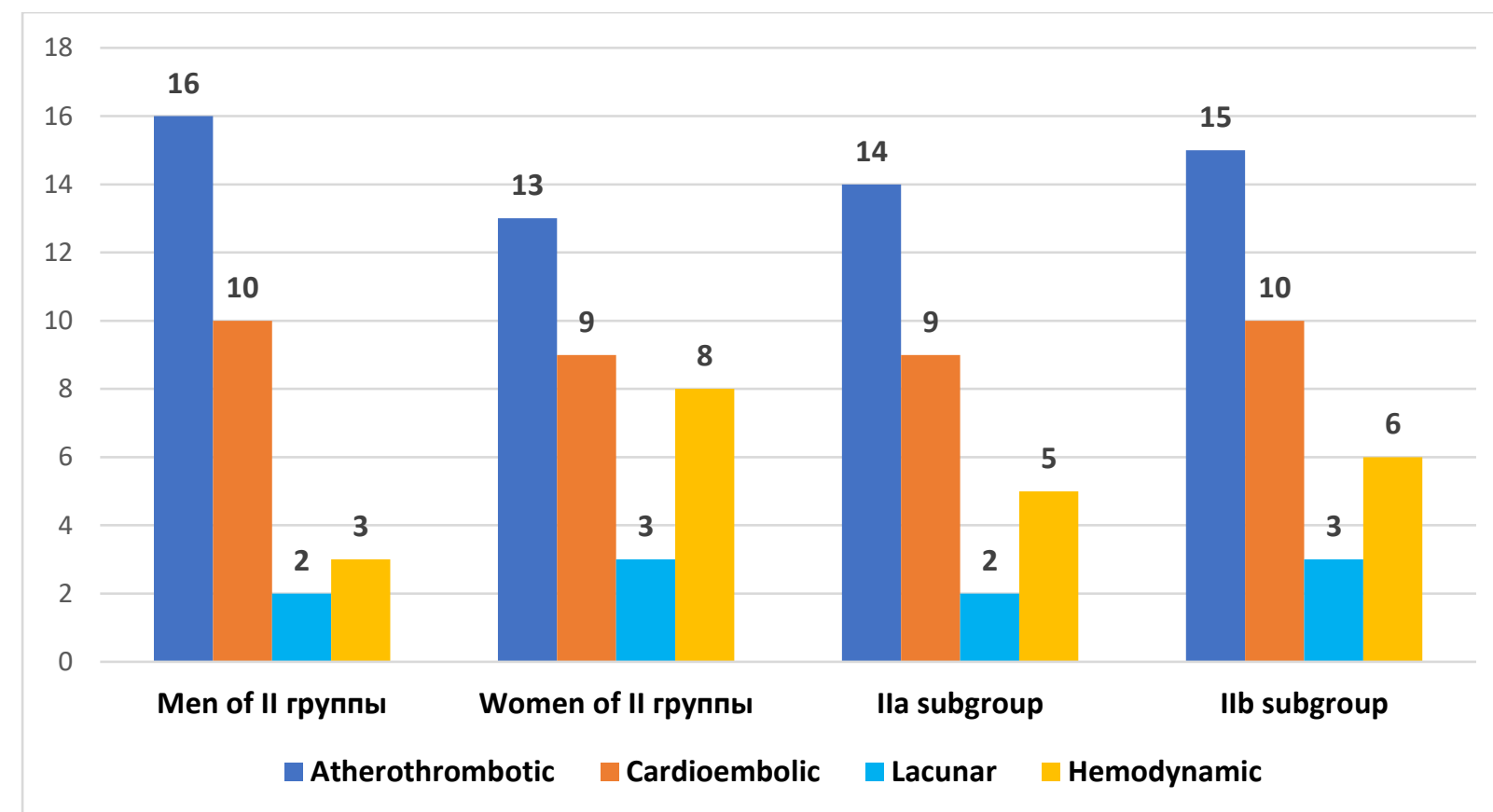

Figure 2 Distribution of patients in group II $(n=64)$ by pathogenetic subtypes by sex and subgroups

Figure 2 shows that the distribution of patients into subgroups according to the pathogenetic subtype of IS was steady, and by gender it was less steady in HD of IS.

The dynamics of indicators of clinical, neurological and neuropsychological scales for pathogenetic subtypes of IS in VI are presented in Table 2.

Patients of group II with CE subtype, as well as patients of group I with CE of IS, gained significantly higher scores on the Rankin scale during the entire ED compared to patients with AT subtype $(p=0.037)$, LA subtype $(p=0.042)$ and HD subtype $(p=0.039)$, which is consistent with literature data [3]. There was no significant relationship between different subtypes of IS with any other indicators, except for the Rankin scale $(-0.14<\mathrm{r}$ $<0.14)$.

In patients of group II, we stated an average direct significant $(\mathrm{p}<0.05)$ relationship between the number of points on the Rankin scale and the number of points on the HADS 
Anxiety scale $(r=0.44)$, HADS Depression $(r=0.46)$ and the scale B. Lindmark $(r=0.47)$ with CE subtype of IS ; average strength, a direct reliable $(p<0.05)$ relationship between the number of points on the Rankin scale and the number of points on the HADS Anxiety scale $(r=0.44)$, HADS Depression $(r=0.48)$ with AT subtype of IS. With LA and HD subtypes of IS in patients of group II, it was not possible to determine the relationship between the indicators of various scales due to the small number of patients.

Table 2

Dynamics of indicators of clinical-neurological and neuropsychological scales of patients of group II $(n=64)$ with different pathogenetic subtypes of IS in VI $(M \pm \sigma)$

\begin{tabular}{|c|c|c|c|c|c|}
\hline \multicolumn{2}{|c|}{ The studied indicators } & $\operatorname{AT}(n=29)$ & CE $(n=19)$ & $\mathrm{LA}(\mathrm{n}=5)$ & $\mathrm{HD}(\mathrm{n}=11)$ \\
\hline \multirow{3}{*}{$\begin{array}{c}\text { B. } \\
\text { Lindmark } \\
\text { Scale }\end{array}$} & ED onset & $324,2 \pm 11,8$ & $310,2 \pm 14,4$ & $327,5 \pm 28,9$ & $326,8 \pm 18,9$ \\
\hline & $\begin{array}{c}\text { in } 3 \\
\text { months }\end{array}$ & $333,4 \pm 11,7$ & $314,3 \pm 13,6$ & $338,4 \pm 29,1$ & $337,3 \pm 19,1$ \\
\hline & $\begin{array}{c}\text { in } 6 \\
\text { months }\end{array}$ & $351,2 \pm 10,4^{*}$ & $329,6 \pm 14,8$ & $362,3 \pm 19,2^{*}$ & $356,8 \pm 18,9$ \\
\hline \multirow{3}{*}{$\begin{array}{l}\text { Index } \\
\text { Barthel }\end{array}$} & ED onset & $44,3 \pm 3,5$ & $38,3 \pm 4,6$ & $46,7 \pm 5,7$ & $45,7 \pm 5,3$ \\
\hline & $\begin{array}{c}\text { in } 3 \\
\text { months }\end{array}$ & $47,5 \pm 3,4$ & $42,4 \pm 4,9$ & $54,6 \pm 6,9$ & $53,8 \pm 6,3$ \\
\hline & $\begin{array}{c}\text { in } 6 \\
\text { months }\end{array}$ & $56,6 \pm 3,8^{*}$ & $48,4 \pm 5,1^{*}$ & $61,4 \pm 7,1^{*}$ & $60,7 \pm 7,4$ \\
\hline \multirow[t]{3}{*}{$\begin{array}{l}\text { Rankin } \\
\text { Scale }\end{array}$} & ED onset & $3,82 \pm 1,29$ & $\begin{array}{c}4,11 \\
\pm 1,23^{* *}\end{array}$ & $3,45 \pm 1,42$ & $3,56 \pm 1,48$ \\
\hline & $\begin{array}{c}\text { in } 3 \\
\text { months }\end{array}$ & $3,40 \pm 1,56$ & $3,76 \pm 1,14^{* *}$ & $3,31 \pm 1,13$ & $3,45 \pm 1,23$ \\
\hline & $\begin{array}{c}\text { in } 6 \\
\text { months }\end{array}$ & $3,04 \pm 0,87$ & $3,51 \pm 1,03^{* *}$ & $2,98 \pm 1,07$ & $3,11 \pm 1,37$ \\
\hline \multirow[t]{3}{*}{ MoCA scale } & ED onset & $21,7 \pm 2,3$ & $20,2 \pm 2,5$ & $23,2 \pm 3,4$ & $22,9 \pm 3,2$ \\
\hline & $\begin{array}{c}\text { in } 3 \\
\text { months }\end{array}$ & $23,7 \pm 2,8$ & $21,9 \pm 2,6$ & $24,8 \pm 3,8$ & $24,5 \pm 3,5$ \\
\hline & $\begin{array}{c}\text { in } 6 \\
\text { months }\end{array}$ & $24,8 \pm 2,3$ & $22,5 \pm 2,5$ & $26,4 \pm 3,9$ & $26,2 \pm 3,6$ \\
\hline \multirow{3}{*}{$\begin{array}{c}\text { HADS } \\
\text { Anxiety }\end{array}$} & ED onset & $10,17 \pm 1,82$ & $10,84 \pm 2,23$ & $8,89 \pm 2,85$ & $9,05 \pm 2,37$ \\
\hline & $\begin{array}{c}\text { in } 3 \\
\text { months }\end{array}$ & $9,84 \pm 1,67$ & $10,18 \pm 2,42$ & $8,32 \pm 2,82$ & $8,48 \pm 2,44$ \\
\hline & $\begin{array}{c}\text { in } 6 \\
\text { months }\end{array}$ & $8,45 \pm 1,42$ & $9,27 \pm 2,14$ & $8,16 \pm 2,76$ & $8,21 \pm 2,65$ \\
\hline \multirow{3}{*}{$\begin{array}{c}\text { HADS } \\
\text { Depression }\end{array}$} & ED onset & $11,23 \pm 1,84$ & $11,96 \pm 1,91$ & $10,48 \pm 2,12$ & $10,27 \pm 2,18$ \\
\hline & $\begin{array}{c}\text { in } 3 \\
\text { months }\end{array}$ & $10,08 \pm 1,68$ & $11,14 \pm 1,67$ & $10,12 \pm 2,34$ & $10,05 \pm 2,56$ \\
\hline & in 6 & $9,34 \pm 1,56$ & $10,34 \pm 1,56$ & $9,08 \pm 2,26$ & $9,18 \pm 2,19$ \\
\hline NIHSS & ED onset & $2,49 \pm 1,72$ & $2,61 \pm 1,58$ & $2,33 \pm 1,97$ & $2,24 \pm 1,87$ \\
\hline
\end{tabular}


Note: * $-\mathrm{P}<0.05$ is significant in relation to the analogous indicators of this group at the onset of the ED; ${ }^{* *}-\mathrm{P}<0.05$ significant in relation to other subtypes of IS in the same period.

Conclusions: 1. Recovery in ED depends on many factors, including the subtype of IS, so the most severe course of CE of IS is reflected in the Rankin scale, the AT subtype also proceeds quite severe, LA and HD subtypes are reliably easier.

2. Each localization of IS in VI is characterized by its own changes in the patient's neurological status, Doppler indices and MRI picture.

3. The timing of the patient's recovery volume depends on the localization of the process, the subtype of IS, the presence of COPD and the rehabilitation technique.

4. Patients with a lacunar subtype, a single small or medium focus in the cerebellar hemispheres and the midbrain, recover most completely after complex rehabilitation.

\section{References:}

1. Иванова Г.Е. Методические рекомендации для пилотного проекта «Развитие системы медицинской реабилитации в Российской Федерации» 2016 - 91с.

2. Машин В.В., Грищук Д.В., Альберт М.А. Факторы и маркеры риска развития различных подтипов ишемического инсульта // Ульяновский медикобиологический журнал. - 2013. - № 1. - С. 8-14.,

3. Хасанов И.А. Клиническая характеристика транзиторных ишемий и инфарктов в вертебробазилярном бассейне в условиях первичного сосудистого центра :Автореф. дис. ... канд. мед. наук. - Казань.: 2017. - 24с.

4. Шамалов Н.А., Кустова М.А. Криптогенный инсульт // Неврология, нейропсихиатрия, психосоматика. - 2014. - Спецвыпуск 2. - С. 42-49.,

5. Duncan P.W., Jorgensen H.S., Wade D.T. Outcome Measures in Acute Stroke Trials: A Systematic Review and Some Recommendations to Improve Practice // Stroke. -2000. Vol. 31. - P. 1429 - 1438

6. Lindmark B. Evaluation of functional capacity after stroke with special emphasis on motor function and activities of daily living // Scand. J. Rehabil. Med. Suppl. - 1988. Vol.21. - P. 1-40

7. Mahoney F.I., Barthel D. Functional evaluation: theBarthel Index. Maryland State Med J 1965; 14:56-61.

8. Shaban A., Albright K.C., Boehme A.K. et al. Circle of Willis Variants: Fetal PCA // Stroke Res Treat (Published online). - 2013. - Vol. 2013 [Электронныйресурс]. Режимдоступа: $\quad$ https://www.ncbi.nlm.nih.gov/pmc/articles/ PMC3618940/pdf/SRT2013-105937.pdf. 